\title{
The role of Malassezia sp., sebum level and trans epidermal water loss (TEWL) toward the dandruff severity between hijab and non hijab wearing subjects
}

\author{
Kristiana Etnawati ${ }^{*}$, Agnes Sri Siswati, Satiti Retno Pudjiati, Devi Artami Susetiati, \\ Dwi Retno Adiwinarni, Affendi Purbananto \\ Department of Dermatology and Venereology, Faculty of Medicine, Public Health, and \\ Nursing, Universitas Gadjah Mada Yogyakarta
}

DOI: http://dx.doi.org/10.19106/JMedScie/0050032018011

\section{ABSTRACT}

Dandruff is a common symptom in adolescence, which possibly due to increasing of Malassezia sp. colonization, sebum level as well as skin hydration. Wearing hijab is predicted to increase the humidity and sebum level lead to increase the number of Malassezia sp. and dandruff severity. A case-control study was conducted on 19 female with dandruff who wear hijab and 19 female with dandruff who do not wear hijab, age between 18 and 27 years old. The dandruff severity was defined clinically using a scoring system (0-100), only subjects with minimum score of 28 will be included in this study. The sebum and trans epidermal water loss (TEWL) levels were measured with Sebumeter and Tewameter from Courage Khazaka. The Malassezia sp. was examined using microscopic examination of the squama and culture in the Saboraud medium. There were no significant differences found between hijab and non-hijab groups for dandruff severity. No difference found between two groups for sebum level, Malassezia $s p$. number microscopically, and Malassezia sp. colonization. Only TEWL level in hijab group that was found to be higher than non-hijab group. Wearing hijab does not increase the dandruff severity, sebum level and colonization number of Malassezia sp. Wearing hijab is found to increase the TEWL level.

\section{ABSTRAK}

Ketombe merupakan gejala umum pada masa remaja, yang disebabkan oleh meningkatnya coloni Malassezia sp., tingkat sebum serta hidrasi kulit. Penggunaan jilbab diperkirakan menyebabkan peningkatan kelembaban dan sebum yang akan meningkatkan jumlah Malassezia sp. dan tingkat keparahan ketombe. Sebuah studi kasus-kontrol dilakukan pada 19 wanita berketombe yang memakai jilbab dan 19 wanita berketombe yang tidak memakai jilbab, usia antara 18 dan 27 tahun. Keparahan ketombe didefinisikan secara klinis menggunakan sistem penilaian (0-100), hanya subjek dengan skor minimal 28 yang akan dimasukkan dalam penelitian ini. Tingkat sebum dan trans epidermal water loss (TEWL) diukur dengan Sebumeter dan Tewameter dari Courage Khazaka. Malassezia sp. diperiksa menggunakan pemeriksaan mikroskopik dari skuama dan kultur dalam medium Saboraud. Tidak ada perbedaan signifikan yang ditemukan antara kelompok hijab dan non-hijab untuk keparahan ketombe. Tidak ada perbedaan yang signifikan ditemukan antara dua kelompok untuk tingkat sebum, jumlah Malassezia $s p$. secara mikroskopis, dan koloni Malassezia sp. Ditemukan tingkat TEWL kelompok berhijab lebih tinggi daripada kelompok non-hijab. Memakai jilbab tidak meningkatkan keparahan ketombe, tingkat sebum, serta jumlah kolonisasi Malassezia sp. Memakai hijab meningkatkan tingkat TEWL.

Keywords: dandruff severity - Malassezia sp - sebum - TEWL - hijab

*corresponding author: etnawati@ugm.ac.id 


\section{INTRODUCTION}

Dandruff, a mild form of seborrhoic dermatitis, is a common complain. It is estimated that half of adolescence population from various race and ethnicity are facing this problem. ${ }^{1,2}$ The high prevalence of dandruff can be witnessed by many anti dandruff products on the market. However nowadays, there are still few medical interventions aimed at this problem. ${ }^{3}$ The pathogenesis of dandruff is still unclear. Some theories are stated by experts such as dandruff caused by commensal bacterial and fungal such as Malassezia sp., high level of sebum, high level of humidity and individual predisposition with the disturbed of skin barrier.

Hijab is commonly used by moslem women in Indonesia. Its importance showed with the finding of various products that are aimed for hair treatment of hijab users. In Indonesian NA-DFC (The National Agency of Drug and Food Control) page, we can find 17 products registered for hair treatment of hijab users and 350 registered products for dandruff. ${ }^{4}$ The scalp of hijab wearing are considered to be more humid which is predicted to raise the dandruff risk through making a better environment for the growth of Malassezia sp. and lowering the barrier of stratum corneum. Indonesia has tropical climate with high humidity through out the year. Therefore, it is need to proof whether dandruff severity, as well as sebum and TEWL levels which reflects skin barrier and the number of Malassezia sp. on hijab wearing female play an important role. This data is needed for the correct choice of scalp treatment products type for hijab users who have dandruff.

\section{MATERIALS AND METHODS}

This study was conducted at Department of Dermatology and Venereology, Faculty of Medicine, Public Health and Nursing, Universitas Gadjah Mada, Yogyakarta. This study was a part of a clinical study of antidandruff shampoo products, and conformed to the ethical guidelines of the Medical and Health Research Ethics Committee (MHREC), Faculty of Medicine, Public Health and Nursing, Universitas Gadjah Mada, Yogyakarta.

\section{Subjects}

The subjects of this study were female who wear hijab as case group and subjects who do not wear hijab as control group. The subjects were matched according to age. The subject included total of 73 female, age between 18 and 40 years old with dandruff severity between 28-56 of Squire method or considered as mild seborrhoic dermatitis. All subjects have signed the informed consent to join the study. The study was started after all subjects underwent "wash-out" period using neutral shampoo without active ingredients for two weeks. ${ }^{5}$ The inclusion criteria were healthy women age 18-40 years, aged matched between hijab and non hijab subjects. The exclusion criteria were pregnancy and lactating. The sample size were determined statistically as 31 .

\section{Scoring dandruff severity}

The clinical examination to defined dandruff severity (according to Squire) was conducted by dermato-venereologist. ${ }^{6}$ The degree of dandruff severity was defined according to dandruff size that attached on the scalp. Using comb and hair clip, strand of hair was separated to see and score the dandruff severity at ten scalp regions. The scores were averaged to defined the dandruff severity of the subject. Sebum level measurement was conducted on four predefined spots using the Sebumeter Courage Khazaka, and TEWL measurement was conducted using the Tewameter Courage Khazaka, the result scores then were averaged.

\section{Microscopic examination}

Microscopic examination of Malassezia $s p$. was conducted by attached an adherence tape that was cut with the size of $1 \mathrm{~cm}^{2}$ on squama in the the dandruff regions for 5 
seconds. The tape then released and attached on object glass and stained with $\mathrm{KOH}$ Parker, then seen under microscope with 1000 magnification. Spores number count per view field (VF) was conducted at $10 \mathrm{VF}$ and the results were then averaged. Malassezia $s p$. colonization was conducted by scrapping skin using scalpel no. 15 and a transparent plastic with a hole in its middle (diameter of $3 \mathrm{~mm}$ ). The skin scraps then were put on the object glass and covered with deck glass and transported to the laboratory to be cultured. The scrap result then was put inside eppendorf tube contained $1 \mathrm{~mL}$ of $\mathrm{NaCl}$ and then vortex for 1 minute. Using oshe that was dipped in the eppendorf tube, we performed swab on SDA medium + cycloheximide + chloramphenicol + olive oil then it was put inside incubator with temperature between 32 and $37{ }^{\circ} \mathrm{C}$ and kept between 3 and 10 days. After 3 - 10 days, the growth colony number were counted using computer programme Image J.

\section{Statistical analysis}

The differences of dandruff severity, sebum level, TEWL, and Malassezia sp. number between hijab and non-hijab groups were tested with statistical programme using the t-test. The correlation between dandruff severity, sebumlevel, TEWL, and Malassezia $s p$. number were statistically analyzed using the Pearson test, with significance was set at $\mathrm{p}<0.05$. The tests were conducted using statistical computer programme.

\section{RESULTS}

\section{Characteristics of subjects}

Thirty eight female subjects suffered from dandruff, consisted of 19 hijab wearing subjects and 19 non hijab wearing subjects with matched age were included in the study. The mean age for hijab wearing subjects was $23.9 \pm 3.4$ years old, and for non hijab wearing subjects was $24.1 \pm 2.7$ years old.

\section{Dandruff severity, sebum level, TEWL, and Malassezia sp.}

Hijab wearing subjects had lower dandruff severity (37.2) compared to non hijab wearing subjects (47.5), however it was statistically not significant $(p>0.05)$. Sebum level of hijab wearing subjects (21.3) was found to be lower than non hijab wearing subjects (26.1) eventhough the difference was not statistically significant $(p>0.05)$. Skin barrier measurement of hijab wearing subjects showed a higher TEWL level (19.2) compared to non hijab wearing subjects (15.8) which was statistically significant $(\mathrm{p}<0.05)$. The average number of Malassezia sp. per microscopic field view of hijab wearing subjects was 8.5 , slightly higher than non hijab wearing subjects (8.4), however this difference was not significant. The colonies number of Malassezia sp.on subjects with dandruff who were wearing hijab (63.28) was higher than non hijab wearing subjects (12.56), however it was not statistically significant $(\mathrm{p}>0.05)$. More detailed information regarding the difference of dandruff severity, TEWL and sebum levels were presented in TABLE 1.

TABLE 1. The comparison of dandruff severity, sebum level, TEWL level, number of Malassezia sp. and colonization number of Malassezia sp. between hijab and non hijab wearing subjects

\begin{tabular}{lccc}
\hline Variable & Hijab (mean \pm SE) & Non-hijab (mean \pm SE) & p \\
\hline Dandruff severity & $37.28 \pm 2.46$ & $47.50 \pm 6.39$ & 0.15 \\
Sebum level $(\mu \mathrm{g} / \mathrm{cm} 2)$ & $21.34 \pm 3.21$ & $26.12 \pm 5.35$ & 0.45 \\
TEWL level $(\mathrm{g} / \mathrm{m} 2 / \mathrm{h})$ & $19.20 \pm 0.87$ & $15.82 \pm 1.06$ & 0.02 \\
Number of Malassezia sp. & $8.53 \pm 2.21$ & $8.44 \pm 2.68$ & 0.97 \\
Colonization of Malassezia sp. & $63.28 \pm 26.47$ & $12.56 \pm 5.34$ & 0.07 \\
\hline
\end{tabular}


The correlation between dandruff severity and sebum level, TEWL, and Malassezia sp.

Analysis of all dandruff subjects found a weak negative correlation and statistically not significant between dandruff severity and sebum level $(r=-0.217 ; \mathrm{p}=$ 0.205). A weak negative correlation and not statistically significant was also found between dandruff severity and TEWL level $(\mathrm{r}=-0.163 ; \mathrm{p}=0.342)$. There was also a weak negative correlation and not significant found between dandruff severity and colonies number of Malassezia sp. $(\mathrm{r}=-0.240, \mathrm{p}=0.164)$. A weak negative correlation and not statistically significant was also found between colonies number of Malassezia sp. and dandruff severity ( $\mathrm{r}=$ $-0.201 ; \mathrm{p}=0.241$ ).

More detailed information regarding the correlation between dandruff severity, sebum and TEWL levels and colonies number of Malassezia sp. of hijab and non hijab wearing subjects were presented in TABLE 2.

TABLE 2. The correlation between dandruff severity with sebum and TEWL levels of hijab and non hijab wearing subjects

\begin{tabular}{lcc}
\hline The correlation between dandruff severity with & Hijab R $=$ & Non-hijab R $=$ \\
\hline Sebum level & -0.15 & -0.28 \\
TEWL level & -0.25 & -0.02 \\
Number of Malassezia sp. & -0.34 & -0.23 \\
Malassezia sp. colonization & -0.27 & -0.21 \\
\hline Correlation with $p>0.05$ & &
\end{tabular}

\section{The correlation between TEWL and Malassezia sp.}

Correlation test between TEWL level and colonies number of Malassezia sp.of hijab wearing subjects showed a moderate power of positive correlation but it was not statistically significant $(\mathrm{r}=0.423 ; \mathrm{p}=0.08)$. A weak negative correlation and not statistically significant $(r=-0.226 ; p=0.367)$ was found in non hijab wearing subjects

\section{DISCUSSION}

Our study found that female population wearing hijab have no difference in term of dandruff severity with non hijab wearing subjects. Neither significant difference found for sebum level between hijab and non hijab wearing subjects nor for colonies number of Malassezia sp. Only an increase of TEWL level was found. It showed that there was decline of skin barrier on hijab wearing subjects with dandruff. In our study, a positive correlation with moderate power was found between TEWL level and colonization of Malassezia $s p$. TEWL is one of objective measurement to define the epidermal barrier power. The TEWL values are varied between different locations of human body surfaces and on each location. There are also different dominant factors that influence the TEWL level. Study by Liu et $a l$. found that the dominant factor influenced TEWL on forehead area was temperature and humidity. The dominant factor on arm area that was covered by clothes, and on palm area the dominant factor was environmental air pressure. ${ }^{7}$ TEWL level could increase with combination of pressure and fabric type. The fabric that is made from polyester can increase the TEWL level twice time than cotton fabric. ${ }^{8}$ The use of hijab give risk to increase the pressure on scalp. The type of fabric used could increase the TEWL level, eventhough it is not closely related with dandruff severity. Our study showed a correlation of dandruff severity 
with colonization of Malassezia sp. The increasing level of TEWL was a sign of reduction instratum corneum barrier that has risk to cause various of scalp disorders. The selection of appropriate fabric type and model of hijab that not cause much pressure on scalp are recommended.

There was a weak negative correlation which is not statistically significant between sebum level, TEWL level and dandruff severity in both hijab and non hijab wearing subjects. A study of subjects which consisted of 59 male and female with dandruff in Shanghai with age range between 18 and 60 years old, also found a negative correlation between dandruff severity and sebum level. ${ }^{8}$ The controversy of sebum and Malassezia sp. role in dandruffis still exist until now. There are some factors that predicted to play a role in dandruff pathogenesis, included individual susceptibility, sebum level, and colonization of Malassezia sp. A study of scalp lipid showed that squalene peroxide was thought to be the factor that play a role indandruff pathogenicity to pass the skin barrier, besides the existence of Malassezia sp. which is thought to be the source of squalene peroxide. ${ }^{9} \mathrm{~A}$ study in Chinese ethnic by $\mathrm{Xu}$ also found a negative correlation between dandruff and sebum and water levels in scalp, and there was no significant correlation found with Malassezia sp.. However there was a strong correlation found with increased number of Staphylococcus, and decreased number of Propionebacterium. It seems that the balance interaction between host and commensal bacteria plays a significant role in dandruff pathogenesis. ${ }^{10,11}$

Our study also showed that the sebum in our dandruff subjects hijab or non hijab still within normal level compared to the data of Thailand population $\left(15 \mu \mathrm{g} / \mathrm{cm}^{2}\right),{ }^{12}$ while the TEWL from our study higher than normal level $\left(13 \mathrm{~g} / \mathrm{m}^{2} / \mathrm{h}\right) \cdot{ }^{13}$ These findings support that dandruff as a mild form of seborrhoic dermatitis is a manifestation of skin barrier disfunction, which showed increasing of TEWL. Dandruff is divided in two types i.e. dry dandruff in which the scalp appears dry, with the flakes small and few, and oily dandruff related to abundant sebum production, in which flakes are thicker, larger and stuck together, forming oily, damp and yellowish patch or the real seborrhoic dermatitis. ${ }^{13-15}$ The subjects of our study were female with dry dandruff. Selection of subjects with mild dandruffis probably caused normal level of sebum which consequently unable to show the correlation between sebum level and dandruff severity. The duration of hijab use was not considered in our study, as well as model and fabric type of hijab and individual sensitiviy factors that influenced dandruff severity such as immune response, neurogenic factor, emossional stress, and nutritional factor.

\section{CONCLUSION}

There is no difference of dandruff severity, sebum level and colonization number of Malassezia sp. between women wearing hijab and not wearing hijab. However, TEWL level is found to be higher in hijab wearing subjects.

\section{ACKNOWLEDGEMENTS}

This study was partly supported by the Community Grant of Faculty of Medicine, Public Health and Nursing, Universitas Gadjah Mada, Yogyakarta in 2016. We are grateful to Adissa Tiara, MD and Danar Wicaksono, MD for the valuable assistances during the study and statistical analysis.

\section{REFERENCES}

1. Elewski BE. Clinical Diagnosis of Common Scalp Disorders. J Investig Dermatology Symp Proc. Elsevier Masson SAS 2005; 10(3):190-3. http://dx.doi.org/10.1111/j.1087-0024.2005.10103.x

2. Bergler-Czop B, Brzezińska-Wcisło L. Dermatological problems of the puberty. Postepy Dermatol Alergol 
2013; 30(3):178-87.

http://dx.doi.org/10.5114/pdia.2013.35621

3. Ranganathan S, Mukhopadhyay $\mathrm{T}$. Dandruff: the most commercially exploited skin disease. Indian J Dermatol 2010; 55(2):130-4.

http://dx.doi.org/10.4103/0019-5154.62734

4. Produk dandruff. Indonesia National Agency of Drug and Food Control (Cited at 2016 February 17 in Bahasa Indonesia). Available from http://cekbpom.pom. go.id/index.php/home/produk/9729b2da38fa3d86c43039e6ad90eb37/10.

5. Franchimont CP, Uhoda EX, Piérard GE. Revisiting dandruff. Int J Cosmet Sci 2006; 28(5):311-8.

http://dx.doi.org/10.1111/j.1467-2494.2006.00326.x

6. Squire R, Goode K. A randomised, single-blind, single-centre clinical trial to evaluate comparative clinical efficacy of shampoos containing ciclopirox olamine (1.5\%) and salicylic acid (3\%), or ketoconazole $(2 \%$, Nizoral) for the treatment of dandruff/seborrhoeic dermatitis. J Dermatolog Treat 2002; 13(2):51-60.

http://dx.doi.org/10.1080/095466302317584395

7. Liu X, Gao Y, Zhang Y, Wang X. Variation in skin biology to climate in Shanghai, China. Cutan Ocul Toxicol 2016; 36(3):231-6.

http://x.doi.org/1080/15569527.2016.1258708

8. Schario $\mathrm{M}$, Tomova-Simitchieva $\mathrm{T}$, Lichterfeld A, Herfert H, Dobos G, Lahmann $\mathrm{N}$, et al. Effects of two different fabrics on skin barrier function under real pressure condition. J Tissue Viability 2017; 26(2):150-5. http://dx.doi.org/10.1016/j.jtv.2016.10.003

9. Jourdain R, Moga A, Vingler P, el Rawadi C, Pouradier F, Souverain L, et al. Exploration of scalp surface lipids reveals squalene peroxide as a potential actor in dandruff condition. Arch Dermatol Res 2016; 308(3):153-63. http://dx.doi.org/10.1007/s00403-016-1623-1

10. Xu Z, Wang Z, Yuan C, Liu X, Yang F, Wang $\mathrm{T}$, et al. Dandruff is associated with the conjoined interactions between host and microorganisms. Sci Rep 2016; 6:24877.

http://dx.doi.org/10.1038/srep24877

11. Clavaud C, Jourdain R, Bar-Hen A, Tichit M, Bouchier C, Pouradier F, et al. Dandruff is associated with disequilibrium in the proportion of the major bacterial and fungal populations colonizing the scalp. PLoS One 2013; 8(3):58203.

http://dx.doi.org/10.1371/journal.pone.0058203

12. Pouradier F,Liu C, Wares J, Yokoyama E, Collaudin C, Panhard S, et al. The worldwide diversity of scalp seborrhoea, as daily experienced by seven human ethnic groups. Int J Cosmet Sci 2017; 39(6): 629-36.

http://dx.doi.org/10.1111/ics.12425

13. Turner GA, Hoptroff M, Harding CR. Stratum corneum dysfunction in dandruff. Int J Cosmet Sci 2012; 34(4):298-306.

http://dx.doi.org/10.1111/j.1468-2494.2012.00723.x

14. Borda LJ and Wikramanayake TC. Seborrheic dermatitis and dandruff: a comprehensive review. J Clin Investigat Dermatol 2015; 3(2):10.

15. Dessini C, Katsambas A. Sebirrhei dermatitis: etiology, risk factors and treatment: facts and controversies. Clin Dermatol 2103; 31-51. http://dx.doi.org/10.1016/j.clindermatol.2013.01.001 